\title{
Optimized Synthesis of Di, Tri and Tetrafused Pyridazinium Cations
}

\author{
Jorge Siró, Andrés Ramos, Juan J. Vaquero, Julio Alvarez-Builla and José L. García-Navío* \\ Departamento de Química Orgánica, Universidad de Alcalá, 28871 Alcalá de Henares, Madrid, Spain
}

Received 15 September 1999; revised 4 January 2000; accepted 20 January 2000

\begin{abstract}
By combining two complementary statistical techniques (fractional factorial experimental design and simplex operation) the synthesis of the parent pyrido[1,2-b]-pyridazinium cation has been successfully carried out (the yield was improved from less than 10 to $65 \%$ ) by basic condensation of 2-methyl-1-aminopyridinium mesitylenesulfonate and $[1,4]$ dioxane-2,3-diol. Using the optimized reaction conditions, other related heterocyclic cations could be prepared, and two interesting examples are now reported. (C) 2000 Elsevier Science Ltd. All rights reserved.
\end{abstract}

One of the most important cytostatic mechanisms of action of coplanar annelated polycyclic compounds is their intercalation into human bDNA. ${ }^{1}$ Some of these molecules are polyheterocyclic cations, with their cationic nature usually being produced by alkylation of the neutral heterocycles, (e.g. the pyridocarbazole derivative elliptinium ${ }^{2}$ or the phenanthridine salt ethidium bromide ${ }^{3}$ ). Less frequently, the cationic atom is shared by two nitrogen heterocycles, such as in the indolo[2,3-a]quinolizinium alkaloid sempervirine. ${ }^{4}$ In recent papers, ${ }^{5}$ we described the synthesis and
DNA intercalating properties of pyridazinium fused heterocycles $\mathbf{1}$, which are examples of this last type of intercalator. These compounds are easily obtained by a double basic condensation between 2-alkyl-1-aminocycloiminium salts and 1,2-dicarbonyl compounds ${ }^{6}$ (Fig. 1). An important limitation to this process, however, is related to the substitution pattern in the non heterocyclic component. To our knowledge, there are only two previous reports describing the synthesis of related parent polyfused heterocyclic cations, $12 b$-azoniaperylene $\mathbf{2}^{7 \mathrm{a}}(55 \%)$ and

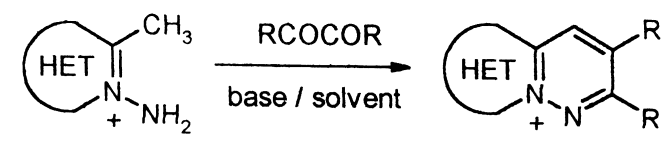

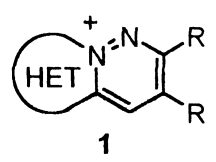

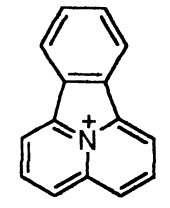

2

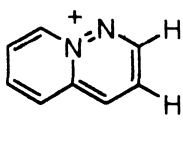

4

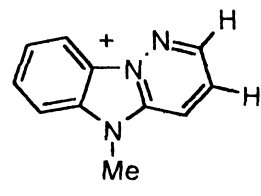

5<smiles>c1cc2cccc3c2c(c1)c1cccc2cccc3[n+]21</smiles>

3

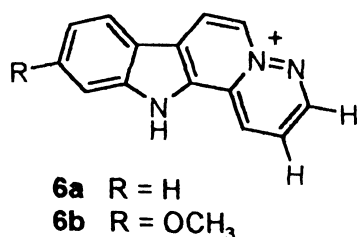

Figure 1. Westphal reaction and examples of polycondensed azonia derivatives.

Keywords: Westphal; condensations; polycyclic heterocyclic ions; computer-assisted methods.

* Corresponding author. Tel.: +34-91-885-4688; fax: +34-91-885-4660; e-mail: qojlgn@quimor.alcala.es 
Table 1. Factors and levels used in $2^{5-1}$ design

\begin{tabular}{lll}
\hline Factors & \multicolumn{2}{c}{ Levels } \\
\cline { 2 - 3 } & Low $(-)$ & High $(+)$ \\
\hline A: Temperature & $30^{\circ} \mathrm{C}$ & $70^{\circ} \mathrm{C}$ \\
B: Reaction time & $1 \mathrm{~h}$ & $4 \mathrm{~h}$ \\
C: Solvent volume & $1 \mathrm{ml}$ & $5 \mathrm{ml}$ \\
D: [1,4]-Dioxane-2,3-diol & $1 \mathrm{mmol}$ & $3 \mathrm{mmol}$ \\
E: Triethylamine & $0.1 \mathrm{mmol}$ & $1.5 \mathrm{mmol}$ \\
\hline
\end{tabular}

$10 c$-azoniafluoranthene salts $\mathbf{3}^{7 \mathrm{~b}}(33 \%)$ (Fig. 1), using [1,4]dioxane-2,3-diol (DODO) as a glyoxal equivalent in this type of condensation process.

In this paper we report an optimized synthesis of new fused bi, tri, and tetracyclic pyridazinium derivatives 4-6. For this purpose, we have initially optimized the synthesis of the unknown pyrido[1,2-b]-pyridazinium cation $\mathbf{4}$, using the sequential application of two complementary statistical optimization techniques (fractional factorial design ${ }^{8,9}$ and simplex procedure ${ }^{8,10}$ ) and we then used these conditions for the synthesis of related heterocyclic cations.

\section{Results and Discussion}

We initially applied the experimental conditions previously described for the synthesis of the azoniaperylene salt $2^{7 \mathrm{a}}$ (using equivalent amounts of 1-amino-2-methylpyridinium mesitylenesulfonate, ${ }^{11}[1,4]$-dioxane-2,3-diol as the glyoxal equivalent, triethylamine, TEA, as the base and ethanol as the solvent) but the expected pyrido[1,2- $a$ ]pyridazinium salt 4 was formed in less than $10 \%{ }^{12}$ Although TEA and DODO seemed to be good choices for the base and glyoxal equivalent, we thought that DMF would be a better choice than $\mathrm{EtOH}$ for the solvent because it would ensure the homogeneity of the reaction mixture, especially for room temperature experiments.

In order to have a rough picture of the influence of the reaction variables - factors in the table-on the response, the five expected to be more significant were chosen (temperature, reaction time, solvent volume, equivalents of [1,4]-dioxane-2,3-diol, and equivalents of triethylamine, leaving fixed the quantity of pyridinium substrate) and with them, a two-level factorial design was built. ${ }^{8 a}$

As a general concept, a factorial design allows building experiments in such a way that the variation of response obtained with different experimental factor settings, permits the experimenter to elaborate a general model of the process, and hence, the contribution of every variable to the response-in this case, the yield. In this way, it is possible not only to analyse the singular influence of every factor, but also to combine influences of two or more variables (interaction terms) and predict how they could affect the yield of the process.

In a two-level factorial design, each factor can take two values, low (-) and high (+) levels, and in this way, the experimental space to be explored is delimited (Table 1). Then, the matrix obtained (Table 2) with the values of the response vector (the yield) for every combination of factor levels, is submitted to multiple regression to obtain a model (Eq. 1), in which the coefficient of every term (either single or interaction) is indicated.

$$
\begin{aligned}
\text { Yield }= & \text { constant }+\mathrm{aF} 1+\mathrm{bF} 2+\mathrm{cF} 3+\mathrm{dF} 4+\mathrm{eF} 5+\mathrm{fF} 6 \\
& +\mathrm{gF} 1 \cdot \mathrm{F} 2+\mathrm{hF} 1 \cdot \mathrm{F} 3+\text { etc } \ldots .
\end{aligned}
$$

No doubt, refining would be required if the model were the final target, but in this case, what is needed is simply to know which terms have the more relevant coefficients $(a, b, c, \ldots n)$, and in which direction. In this case, a fractional factorial design is a better choice, as it allows roughly the same information to be obtained with $50 \%$ of the experiments.

Table 2 shows the matrix for the $2^{5-1}$ fractional factorial design with the yields for each of the 16 runs. Then, the multiple regression process produced the coefficients, shown in Table 3, for every single term as well as those from the binary interactions, which in a fractional factorial design are usually smaller. The analysis of the results shows two terms having the coefficients with more influence on the final yield. ${ }^{8}$ Thus, these two factors were chosen to perform a basic SIMPLEX optimisation, ${ }^{10}$ starting from the best experience $\left(80^{\circ} \mathrm{C}\right.$ and $2 \mathrm{mmol}$ of triethylamine), raising both factors $5^{\circ} \mathrm{C}$ and $0.2 \mathrm{mmol}$ in each experiment.

\begin{tabular}{|c|c|c|c|c|c|c|}
\hline Exp. & Temp. & Reaction time & Solvent volume & {$[1,4]$-Dioxane-2,3-diol } & Triethylamine & Yield (\%) \\
\hline 1 & - & - & + & - & - & 0 \\
\hline 2 & + & - & - & - & - & 7 \\
\hline 3 & - & - & - & + & - & 0 \\
\hline 4 & + & - & + & + & - & 11 \\
\hline 5 & - & + & - & - & - & 3 \\
\hline 6 & + & + & + & - & - & 12 \\
\hline 7 & - & + & + & + & - & 1 \\
\hline 8 & + & + & - & + & - & 16 \\
\hline 9 & - & - & - & - & + & 9 \\
\hline 10 & + & - & + & - & + & 36 \\
\hline 11 & - & - & + & + & + & 15 \\
\hline 12 & + & - & - & + & + & 28 \\
\hline 13 & - & + & + & - & + & 10 \\
\hline 14 & + & + & - & - & + & 30 \\
\hline 15 & - & + & - & + & + & 19 \\
\hline 16 & + & + & + & + & + & 43 \\
\hline
\end{tabular}

Table 2. Experimental design matrix 
Table 3. Main and interaction effects upon yield

\begin{tabular}{lllr}
\hline $\begin{array}{l}\text { Factors } \\
\text { (confounded with) }\end{array}$ & Effects & $\begin{array}{l}\text { Factors } \\
\text { (confounded with) }\end{array}$ & Effects \\
\hline A (BCDE) & 15.75 & AE (BCD) & 5.25 \\
B (ACDE) & 3.50 & BC (ADE) & -2.50 \\
C (ABDE) & 2.00 & BD (ACE) & 2.75 \\
D (ABCE) & 3.25 & BE (ACD) & 0.00 \\
E (ABCD) & 17.50 & CD (ABE) & -0.25 \\
AB (CDE) & 1.25 & CE (ABD) & 2.50 \\
AC(BDE) & 3.25 & DE (ABC) & 1.75 \\
AD (BCE) & 0.00 & & \\
\hline
\end{tabular}

All experiments performed are indicated with the yield in Table 4, where the best experiment showed a yield of $61 \%$ for the process.

Unfortunately, we have only been able to increase the yield from 55 to $61 \%$, but this makes us think that we selected a good experimental region so that the results and experimental yields reach the highest possible value.

The best conditions obtained (in relation to 1 equiv. of the starting $N$-amino-cycloiminium salt, [1,4]-dioxane-2,3-diol, DODO, (1.2 equiv.)/TEA ( 1.2 equiv.)/DMF $\left./ 70^{\circ} \mathrm{C}\right)$ were then applied to obtain the new tricyclic 5-methyl-5Hpyridazino[1,6- $a$ ] benzimidazolium mesitylenesulfonate $\mathbf{5}$ $(90 \%),{ }^{13}$ the tetracyclics $11 H$-pyridazino $\left[2^{\prime}, 3^{\prime}: 1,2\right]$-pyrido$[3,4-b]$ indolium mesitylenesulfonate $6 \mathbf{a}(65 \%)$ and the 9-methoxy substituted derivative $6 \mathbf{b}(70 \%)$ (Fig. 1), which are isoelectronic with the alkaloids sempervirine ${ }^{14}$ and flavocorylene $^{15}$ (Fig. 1). The methodology which is currently being used on other related systems and results, both in the synthetic field and their biological applications, will be described in due course.

\section{Experimental}

\section{General methods}

Melting points were determined on a Büchi SMP-20 and are uncorrected. IR spectra were recorded as $\mathrm{KBr}$ discs using a Perkin-Elmer 700 or 1310 spectrophotometer. ${ }^{1} \mathrm{H}$ NMR spectra were obtained on a Varian Unity $300(300 \mathrm{MHz})$ spectrometer in DMSO- $\mathrm{d}_{6}$, using tetramethylsilane as an internal reference. All chemical shifts $(\delta)$ and coupling constant $(J)$ values are expressed in units of ppm and $\mathrm{Hz}$, respectively. All statistical tests required for analysis of experiments were calculated using the program, OPTIMUs. ${ }^{16}$ The starting $N$-amino- $\alpha$-methylcycloiminium salts were obtained as previously described by amination with $\mathrm{O}$-(mesitylenesulfonyl)hydroxylamine (MSH) of the corresponding pyridine, ${ }^{11}$ benzimidazole ${ }^{6}$ and $\beta$-carboline ${ }^{15}$ derivatives.

Pyrido[1,2-a]pyridazinium bromide 4. $N$-amino-2methylpyridinium mesitylenesulfonate $(0.40 \mathrm{~g}, 1.3 \mathrm{mmol})$, and triethylamine $(0.16 \mathrm{~g}, 1,6 \mathrm{mmol})$ in DMF $(200 \mathrm{~mL})$ were stirred at $70^{\circ} \mathrm{C}$. To the resulting solution was added in one portion [1,4]dioxane-2,3-diol $(0.19 \mathrm{~g}, 1.6 \mathrm{mmol})$, and the mixture was stirred at this temperature for $1 \mathrm{~h}$. Concentrated $\mathrm{HBr}(1 \mathrm{~mL}, 48 \%)$ was then added and the resulting solution was evaporated under reduced pressure. The residue was dissolved in methanol, decoloured with charcoal and then filtered on Celite. The residue obtained by removing the solvent became solid when rinsed with acetone $(0.15 \mathrm{~g}) . \mathrm{mp}>300^{\circ} \mathrm{C}$ (white powder from $\mathrm{MeOH}$ ). Yield: $61 \%$. IR $\nu_{\max } 3104,3011,2926,1639,1617,1467,1439$, $1399,1320,1239,1167,1146,1045,830 \mathrm{~cm}^{-1} .{ }^{1} \mathrm{H}$ NMR $\left(300 \mathrm{MHz}, \mathrm{CD}_{3} \mathrm{OD}\right) \delta 9.59(\mathrm{dd}, J=6.9$ and $0.9 \mathrm{~Hz}, 1 \mathrm{H})$, $9.40(\mathrm{dd}, J=4.7$ and $2.3 \mathrm{~Hz}, 1 \mathrm{H}), 8.80(\mathrm{dd}, J=9.0$ and $2.3 \mathrm{~Hz}, 1 \mathrm{H}), 8.64-8.69$ (m, $2 \mathrm{H}$ ), 8.30 (ddd, $J=6.9,5.7$ and $3.5 \mathrm{~Hz}, 1 \mathrm{H}), 8.13(\mathrm{dd}, J=9.0$ and $4.7 \mathrm{~Hz}, 1 \mathrm{H})$ ppm. ${ }^{13} \mathrm{C}$ NMR $\left(50 \mathrm{MHz}, \mathrm{CD}_{3} \mathrm{OD}\right) \delta 154.0,142.6,142.2$, 136.0, 129.4, 128.4, 128.0, $110.3 \mathrm{ppm}$. Anal. Calcd for $\mathrm{C}_{8} \mathrm{H}_{7} \mathrm{~N}_{2} \mathrm{Br}$ (211.06): C, 45.53; H, 3.34; N, 13.27. Found: C, 45.30; H, 3.45; N, 13.02 .

5-Methyl-5H-pyridazino[1,6- $a]$ benzimidazolium mesitylenesulfonate 5. The hot mixture of 1-amino-2,3-dimethylbenzimidazolium salt $(0.47 \mathrm{~g}, 1.3 \mathrm{mmol})$, and triethylamine $(0.16 \mathrm{~g}, 1.6 \mathrm{mmol})$ in $\mathrm{DMF}(200 \mathrm{~mL})$ was stirred at $70^{\circ} \mathrm{C}$ with $[1,4]$ dioxane-2,3-diol $(0.19 \mathrm{~g}, 1.6 \mathrm{mmol})$ for $1 \mathrm{~h}$. The reaction mixture was evaporated under reduced pressure and the residue precipitated with ethyl acetate. The solid was washed with acetone to yield a white powder $(0.45 \mathrm{~g}$, $90 \%) \mathrm{mp}\left(235-236^{\circ} \mathrm{C}\right.$ from EtOH/EtOAc). IR $\nu_{\max } 3045$, 3016, 2981, 2929, 1609, 1547, 1527, 1469, 1402, 1331, 1187, 1080, 1011, 788, 772, 753, 724, $620 \mathrm{~cm}^{-1} .{ }^{1} \mathrm{H}$ NMR $\left(500 \mathrm{MHz}, \mathrm{CD}_{3} \mathrm{OD}\right) \delta 9.24(\mathrm{~d}, J=3.7 \mathrm{~Hz}, 1 \mathrm{H}), 9.00(\mathrm{~d}$, $J=9.3 \mathrm{~Hz}, 1 \mathrm{H}), 8.48(\mathrm{~d}, J=8.3 \mathrm{~Hz}, 1 \mathrm{H}), 8.24-8.28(\mathrm{~m}, 2$ H), 7.98 (app. t, $J=7.8 \mathrm{~Hz}, 1 \mathrm{H}), 7.84$ (app. t, $J=7.8 \mathrm{~Hz}, 1$ H), $6.70(\mathrm{~s}, 2 \mathrm{H}), 4.25$ (s, $3 \mathrm{H}), 2.46(\mathrm{~s}, 6 \mathrm{H}), 2.14(\mathrm{~s}, 3 \mathrm{H})$ ppm. ${ }^{13} \mathrm{C}$ NMR (125 MHz, DMSO-d 6 ) $\delta 184.2,180.3,177.8$, $173.7,173.6,169.4,167.5,167.3,166.7,165.1,163.8$, $158.9,150.8,150.7,68.4,60.2,57.8$ ppm. Anal. Calcd for $\mathrm{C}_{20} \mathrm{H}_{21} \mathrm{~N}_{3} \mathrm{O}_{3} \mathrm{~S}$ (383.47): C, 62.64; H, 10.96; N, 5.52. Found: C, 62.33; H, 11.32; N, 5.58.

$11 H$-Pyridazino $\left[1^{\prime}, 6^{\prime}: 1,2\right]$ pyrido $[3,4-b]$ indolinium mesitylenesulfonate $6 \mathbf{a}$. This compound was obtained as before for 5 but the isolation procedure was slightly different. The crude reaction mixture, obtained by evaporation under reduced pressure, was purified by column chromatography

Table 4. Simplex experiments in the optimisation

\begin{tabular}{|c|c|c|c|c|c|c|c|}
\hline Exp. & TEA (mmol) & Temp. $\left({ }^{\circ} \mathrm{C}\right)$ & Yield (\%) & Exp. & TEA (mmol) & Temp. $\left({ }^{\circ} \mathrm{C}\right)$ & Yield (\%) \\
\hline 1 & 2 & 80 & 55 & 8 & 1.8 & 65 & 56 \\
\hline 2 & 1.8 & 80 & 56 & 9 & 1.6 & 70 & 61 \\
\hline 3 & 2 & 75 & 58 & 10 & 1.6 & 75 & 56 \\
\hline 4 & 1.8 & 75 & 57 & 11 & 1.6 & 65 & 56 \\
\hline 5 & 2 & 70 & 60 & 12 & 1.4 & 65 & 57 \\
\hline 6 & 1.8 & 70 & 59 & 13 & 1.4 & 70 & 59 \\
\hline 7 & 2 & 65 & 56 & & & & \\
\hline
\end{tabular}


on silica gel using $\mathrm{Cl}_{2} \mathrm{CH}_{2} / \mathrm{MeOH}(9: 1)$ as eluent to give the product as a yellow powder $(0.44 \mathrm{~g}, 65 \%)$. mp $\left(288-289^{\circ} \mathrm{C}\right.$ from $\mathrm{MeOH})$. IR $\nu_{\max } 3125,3050,2966,1655,1482,1450$, $1421,1321,1280,1206,1167,1087,1011,678 \mathrm{~cm}^{-1} .{ }^{1} \mathrm{H}$ NMR (200 MHz, CD 3 OD) $\delta 9.24$ (dd, $J=9.1$ and $1.5 \mathrm{~Hz}$, $1 \mathrm{H}), 8.99(\mathrm{dd}, J=4.5$ and $1.6 \mathrm{~Hz}, 1 \mathrm{H}), 8.47(\mathrm{~d}, J=8.9 \mathrm{~Hz}$, $1 \mathrm{H}), 8.11(\mathrm{dd}, J=9.2$ and $1.4 \mathrm{~Hz}, 1 \mathrm{H}), 8.00(\mathrm{~d}, J=8.9 \mathrm{~Hz}$, $1 \mathrm{H}$ ), 7.89 (app. t, $J=7.3 \mathrm{~Hz}, 1 \mathrm{H}$ ), 7.60 (app. t, $J=7.3 \mathrm{~Hz}$, $1 \mathrm{H}), 6.79$ (s, $2 \mathrm{H}), 2.64$ (s, $6 \mathrm{H}), 2.18$ (s, $3 \mathrm{H}) \mathrm{ppm}$. Anal. Calcd for $\mathrm{C}_{23} \mathrm{H}_{21} \mathrm{~N}_{3} \mathrm{O}_{3} \mathrm{~S}$ (419.51): C, 65.85; H, 5.05; N, 9.02. Found: C, 65.75; H, 5.25; N, 9.32.

9-Methoxy-11H-pyridazino $\left[1^{\prime}, 6^{\prime}: 1,2\right]$ pyrido $[3,4-b]$ indolinium mesitylenesulfonate $\mathbf{6 b}$. Obtained as $\mathbf{6 a}$ (yellow powder $0.42 \mathrm{~g}, 70 \%)$. $\mathrm{mp}\left(238-239^{\circ} \mathrm{C}\right.$ from $\mathrm{MeOH} /$ EtOAc). IR $\nu_{\max } 3100,3020,2947,1628,1570,1482$, $1450,1421,1321,1280,1206,1167,1087,1011$, $678 \mathrm{~cm}^{-1}$. ${ }^{1} \mathrm{H}$ NMR (200 MHz, CD $\left.3 \mathrm{OD}\right) \delta 9.33(\mathrm{dd}$, $J=9.2$ and $1.5 \mathrm{~Hz}, 1 \mathrm{H}), 9.02(\mathrm{dd}, J=4.6$ and $1.5 \mathrm{~Hz}, 1 \mathrm{H})$, $8.98(\mathrm{~d}, J=6.9 \mathrm{~Hz}, 1 \mathrm{H}), 8.54$ (d, J=6.9 Hz, $1 \mathrm{H}), 8.09$ $(\mathrm{d}, J=8.9 \mathrm{~Hz}, 1 \mathrm{H}), 7.86(\mathrm{dd}, J=9.2$ and $4.6 \mathrm{~Hz}, 1 \mathrm{H})$, $7.18(\mathrm{~d}, J=2.1 \mathrm{~Hz}, 1 \mathrm{H}), 7.00(\mathrm{dd}, J=8.9$ and $2.1 \mathrm{~Hz}, 1 \mathrm{H})$, 6.79 (s, $2 \mathrm{H}), 3.90$ (s, $3 \mathrm{H}), 2.64$ (s, $6 \mathrm{H}), 2.18$ (s, $3 \mathrm{H}) \mathrm{ppm}$. ${ }^{13} \mathrm{C}$ NMR $\left(50 \mathrm{MHz}, \mathrm{CD}_{3} \mathrm{OD}\right) \delta 163.8,150.1,146.3,139.7$, $139.4,137.4,131.3,131.1,130.8,129.0,128.7,124.7$, $123.5,117.1,115.0,114.3,109.3,95.2,56.1,23.1$, 20.9 ppm. Anal. Calcd for $\mathrm{C}_{24} \mathrm{H}_{23} \mathrm{~N}_{3} \mathrm{O}_{4} \mathrm{~S}$ (449.53): C, 64.13; H, 5.16; N, 9.35. Found: C, 63.95; H, 5.10; N, 9.42.

\section{Acknowledgements}

The authors wish to acknowledge the Spanish Comision Interministerial de Ciencia y Tecnologia (project SAF 98-0093) and the University of Alcala (Madrid, Spain) for financial support and studentship (J. S.) from the Ministerio de Educación y Ciencia is gratefully acknowledged.

\section{References}

1. Pindur, U.; Haber, M.; Sattler, K. J. Chem. Ed. 1993, 70, 263-272. 2. (a) Gribble, G. W. The Alkaloids; Brossi, A. Ed.; Academic Press, 1990; Vol. 39, p 239. (b) Meunier, G.; de Montauzon, G.; Bernardou, J.; Grassy, G.; Bonnafous, M.; Cros, S.; Meunier, B. Mol. Pharmacol. 1988, 33, 93-102.

3. Wakelin, L. P.; Waring, M. J. J. Mol. Biol. 1980, 144, 183-214. 4. Caprasse, M.; Houssier, C. Biochimie 1984, 66, 31-41.

5. (a) Martinez-Barrasa, V.; Burgos C.; Izquierdo M. L.; AlvarezBuilla, J.; Vaquero, J. J. Tetrahedron Lett. 1999, 40, 4115-4118. (b) Molina, A.; Vaquero, J. J.; García-Navío, J. L.; Alvarez-Builla, J.; Gago, F.; de Pascual-Teresa, B.; Rodrigo, M. M. J. Org. Chem. 1999, 64, 3907-3915. (c) Siro, J. G.; Pastor, J.; García-Navío, J. L.;
Vaquero, J. J.; Alvarez-Builla, J. Tetrahedron 1998, 54, 1929_ 1936. (d) Pastor, J.; Siro, J.; García-Navío, J. L.; Vaquero, J. J.; Alvarez-Builla, J.; Gago, F.; de Pascual-Teresa, B.; Pastor, M.; Rodrigo, M. M. J. Org. Chem. 1997, 62, 5476-5483. (e) Molina, A.; Vaquero, J. J.; García-Navío, J. L.; Alvarez-Builla, J.; de Pascual-Teresa, B.; Gago, F.; Rodrigo, M. M.; Ballesteros, M. J. Org. Chem. 1996, 61, 5587-5599. (f) Molina, A.; Vaquero, J. J.; García-Navío, J. L.; Alvarez-Builla, J.; Castaño, O.; de Andrés, J. L.; Rodriguez, M. M. J. Org. Chem. 1996, 5587-5599. (g) Pastor, J.; Siro, J. G.; García-Navío, J. L.; Vaquero, J. J.; Rodrigo, M. M.; Ballesteros, M.; Alvarez-Builla, J. BioMed. Chem. Lett. 1995, 5, 3043-3048. (h) Santiesteban, I.; Siro, J. G.; Vaquero, J. J.; García-Navío, J. L.; Alvarez-Builla, J.; Castaño, O. J. Org. Chem. 1995, 60, 5667-5673.

6. Matia, M. P.; García-Navío, J. L.; Vaquero, J. J.; AlvarezBuilla, J. Liebigs Ann. Chem. 1992, 777-779.

7. (a) Fourmigué, M.; Eggert, H.; Bechgaard, K. J. Org. Chem. 1991, 56, 4858-4864. (b) Fourmigué, M.; Boubekeur, K.; Batail, P.; Bechgaard, K. Angew. Chem. Int. Ed. Engl. 1989, 28, 588-590. 8. Several excellent monographs can be used to illustrate experimental designs as well as other optimization methods, some examples in: (a). Carlson, R. Design and Optimization in Organic Synthesis; Elsevier: Amsterdam; 1992. (b) Morgan, E. Chemometrics: Experimental Design; Wiley: London; 1991; p 81-177. (c) Box, G. E. P.; Hunter, W. G.; Hunter, J. S. Statistics for the experimenters: An introduction to design, data analysis and model building; Wiley: New York; 1977.

9. See for example: Chubb, F. L.; Edward, J. T.; Wong, S. C. J. Org. Chem. 1980, 45, 2315-2324 and Johnstone, R. A. W.; Nunes, M. L. P. G.; Pereira, M. M.; Rocha Gonzalves, A. M.d'A; Serra, A. C. Heterocycles 1996, 43, 1423-1437.

10. Spendley, W.; Hext, G. R.; Himsworth, F. R. Technometrics 1962, 4, 441-456.

11. Matia, M. P.; García-Navío, J. L.; Vaquero, J. J.; AlvarezBuilla, J. J. Heterocycl. Chem. 1990, 27, 661-665.

12. The ratios of the azaquinolinium cation vs the starting pyridinium salt were estimated from the relative integration of characteristic resonances in the ${ }^{1} \mathrm{H}$ NMR of the crude reaction mixtures.

13. In this synthetic approach, the benzimidazole nitrogen should be substituted, otherwise the basic condensation process between the starting $N$-aminobenzimidazolium salt and the $\alpha$-dicarbonile would not take place.

14. Potts, K. T.; Mattingly, G. S. J. Org. Chem. 1968, 45, 39853987.

15. Matia, M. P.; Ezquerra, J.; García-Navío, J. L.; Vaquero, J. J.; Alvarez-Builla, J. Tetrahedron Lett. 1991, 51, 7575-7578.

16. Ramos, A.; Alvarez-Builla, J. Universidad de Alcalá. OPTiMUs is an object oriented program which runs under Windows 3.1 or '95 and implements some of the more popular algorithms for process optimization. Beta versions would be supplied to non-profit organisations under request. 